\title{
Digital Skills and Literacy among Prospective Teachers of Sukkur Pakistan: A Conceptual Framework
}

\author{
Muhammad Mujtaba Asad a, Jannat Gul b, Muhammad Aslam Lashari \\ Sukkur IBA University \\ ${ }^{a}$ E-mail address m.mujtaba@iba-suk.edu.pk.; ${ }^{b}$ E-mail address jannatgul.bedf19@iba-suk.edu.pk
}

\begin{abstract}
The importance of information and communication technologies in the teaching and learning process has been highlighted several times in different studies worldwide. Digital literacy is a serious concern to prospective teachers because they are the main source for students to learn about digital tools and technologies to compete with others and it is only possible when teachers are digitally literate and eager to accept this as a need for 21st-century education. According to National Education Policy 2017 (the main pillars of ICT policy are the use of information and communication technologies (ICT) to strengthen the quality of teaching and enhance student learning and develop complementary approaches to ICT in education) and in light of 4th goal (Quality Education) of the Sustainable Development Goals (SDGs) it is significant for the integration of ICT in teaching and learning process in Pakistan. Whereas, the objective and proposed hypothesis of this study are to assess whether the teachers are digitally literate or interested to accept this digital transformation in education. In the context of methodology, for assessing the digital literacy among the student-teachers the data will be collected through a quantitative research approach from approximately 200 students of the Education department at Sukkur IBA University. Whereas, the gathered data will be analyzed by using the SPSS software by using Mann-Whitney-U Test and Independent Sample T-Test. The expected outcome of this research will be helpful to ensure the quality education and integration of ICT in teaching and learning processes for the betterment of the Educational system in Sindh, Pakistan because our educational system is so backward in technology. In conclusion, this study will enhance the knowledge and technological skills of prospective teachers through ICT integration. It will also increase the interest of prospective teachers in digital literacy through ICT based training.
\end{abstract}

Keywords: Digital Literacy, Prospective Teachers, ICT Educational Policy, Quantitative Study

This is an open access article under the CC-BY-NC license.

\section{INTRODUCTION}

The world is getting digitized as technology is taking place everywhere in Medical, Engineering, Trade, Home, Economics, Accountings in every field technology has its importance. In Education technology is playing its special role. In this Modern era of IR 4.0, technology has enhanced learning through different perspectives such as to form latest and modern skilled syllabus, 
to rectify the safeguard of the students, management of data for students and making the better process of admission and examination, teachers' report and online training programs to have a healthy learning environment and make learning more productive.

In Pakistan according to National professional standards for teachers(NPSTs) initial preparation of instructors in Pakistan it is focused that teachers must have effective communication and should know skillful use of Digital technologies. Market Data Retrieval (MDR) reported in 2002 that across the United States $98 \%$ of schools and $77 \%$ of classrooms are connected to the Internet but in Pakistan still in 2019 technology in the education system is not to that extent. As compared to other countries we are not providing skills that are needed by 21 st-century students, we are not making them able to compete with this digital revolution that has taken place in this world so far. To provide these 21 st-century skills to students it is significant for instructors to be skilled in information technology. Teachers need to be digitally trained as the 21 st century needs communicative, collaborative, critical thinkers, and creativity based teachers. Pakistan National policy 2017 has drawn a lot of attention towards the integration of ICT in Education and making it the main factor for teachers to be digitally literate. To make our Education system effective and to be on the 4th goal (Quality Education) of Sustainable Development Goals (SDGs) the teachers must be Digitally Literate.

Students are the future of every nation, the same as student-teachers are one of them who are going to bring the revolution of digital media into education. However (Noor-Ul-Amin, 2013) reported that most countries are looking towards ICT for raising educational standards. Research indicates that to integrate ICT in the education system, teachers have to have access to relevant equipment, workplace support, and positive attitudes towards technology (Kopcha; 2012). Further, According to Bhattacharjee B (2016), Digital technologies are of great importance for prospective teachers during education programs in the 21st Century, because without information technology teachers cannot manage the class as per 21st-century need. By using digital technology and getting a perception of Information and communication technology, student-teachers will become a conducive teacher. Information communication technology plays a basic role in the changing nature of education and changing the work of students and teachers in the teaching and learning process. Digital technology is the main factor in our society for rapid changes... So we are going to conduct this Quantitative research from the prospective Teachers of Sukkur IBA University for assessing their level of Digital literacy and their competency to bring this digital revolution.

\subsubsection{Problem Statement}

Sindh is almost covered with rural areas. The UN report for 2014-15 shows alarming poverty of $75.5 \%$ in rural areas, so due to poverty, their people can't afford quality education due to the lack of resources. According to N Saeed ( 2015) In Backcountry, there is not a much approach to instructional institutions specifically at higher levels of education. School infrastructure is not so good, the Classroom is not well managed. Many schools have a lack of classrooms. In our areas, Students often face difficulty in using information and technology. Moreover, students do not have access to technology. According to the survey report 2014-15 that women's literacy rate in rural Sindh is just $20 \%$ due to gender discrimination. Whereas, according to the United States 2005 stated that ICT can be a powerful catalyst for political and social empowerment for women. Most of the parents did not allow their daughters to get a quality education due to social concerns. On the other side, Male children have enough freedom and facilities to get an education. (Sheila M.Smith;2005).

Furthermore, in the existing school's teachers are using same traditional practices which ones their teacher had practiced on them and which ones they had studied in their curriculum so far as they are not updating their curriculum and new teaching strategies based on this modern era of technology and innovation (EMM Asad;2013).In this technological era, teachers need to be familiar with the latest digital technologies and ICTs and should be able to integrate them into their teaching 
and learning practice (NPS for teachers in Pakistan). As it will be very essential for a good teacher to be digital and computer literate and make his teaching process more interesting and effective (National policy of Pakistan 2017). So it is only possible when they will use technology such as multimedia, projectors, online quizzes, etc in their classroom for enhancing learning in different styles (MN Tunio; 2013).

In the current scenario where the COVID-19 pandemic has made a great change in the life of individuals, it also affects the educational sector. Most of the public schools are closed and open schools are facing huge difficulties to provide the quality education. It is all due to the less efficiency of Teachers in ICT related learning, they had chosen before traditional teaching methods and now to adopt the e-learning system is too challenging for them. If schools and teachers have adapted the concept of learning with technology before, they have not to face such a tough time and loss in the education system. So for a better future, it is very important to bring technology in the teaching and learning process and it is possible when our prospective teachers are digitally literate.

\subsubsection{Research Objectives}

These research question has been designed by focusing 4Cs of learning in the $21^{\text {st }}$ century

C. To analyze the communication skills of digital literacy among male and female prospective teachers of Sukkur IBA University.

CI. To specify the collaborative skills of digital literacy among male and female prospective teachers of Sukkur IBA University.

CII. To guess the creativity skills of digital literacy among male and female prospective teachers of Sukkur IBA University.

CIII. To evaluate the critical thinking skills of digital literacy among male and female

Prospective teachers of Sukkur IBA University.

\subsubsection{Research Questions}

This quantitative research study is based on the following questions

1. What are the communication skills of digital literacy among male and female prospective teachers of Sukkur IBA University?

2. What are the collaborative skills of digital literacy among male and female prospective teachers of Sukkur IBA University?

3. What are the creative skills of digital literacy among male and female prospective teachers of Sukkur IBA University?

4. What are the critical thinking and decision making skills of digital literacy among male and female prospective teachers of Sukkur IBA University?

\subsubsection{Hypothesis}

The following research hypothesis has been designed to achieve the proposed research outcome.

Null hypothesis.

There is no significant difference in the mean score of digital literacy among male and female prospective teachers of Sukkur IBA University. 


\subsubsection{Conceptual Framework}

This research will be conducted based on 4C's of learning skills in the 21 st century that are communication, Critical thinking, collaboration, and creativity. Communication in the twenty-first century is an effective tool. In every field, you need an effective way of communication to exchange and impart information. Similarly, without collaborative skills, anyone can't effectively communicate. As to build and maintain good relationships with others, effective communication plays a vital role. Critical thinking and creativity is also an important part as it increases a higher level of cognition and makes you a better problem solver and a good decision-maker. It helps you to think logically. Creativity makes us able to see things from different perspectives and build your innovative skills.

This research will be conducted from the male and female perspective teachers of the Education Department of Sukkur IBA University. A Quantitative Research approach will be used to assess Digital Literacy among prospective teachers.

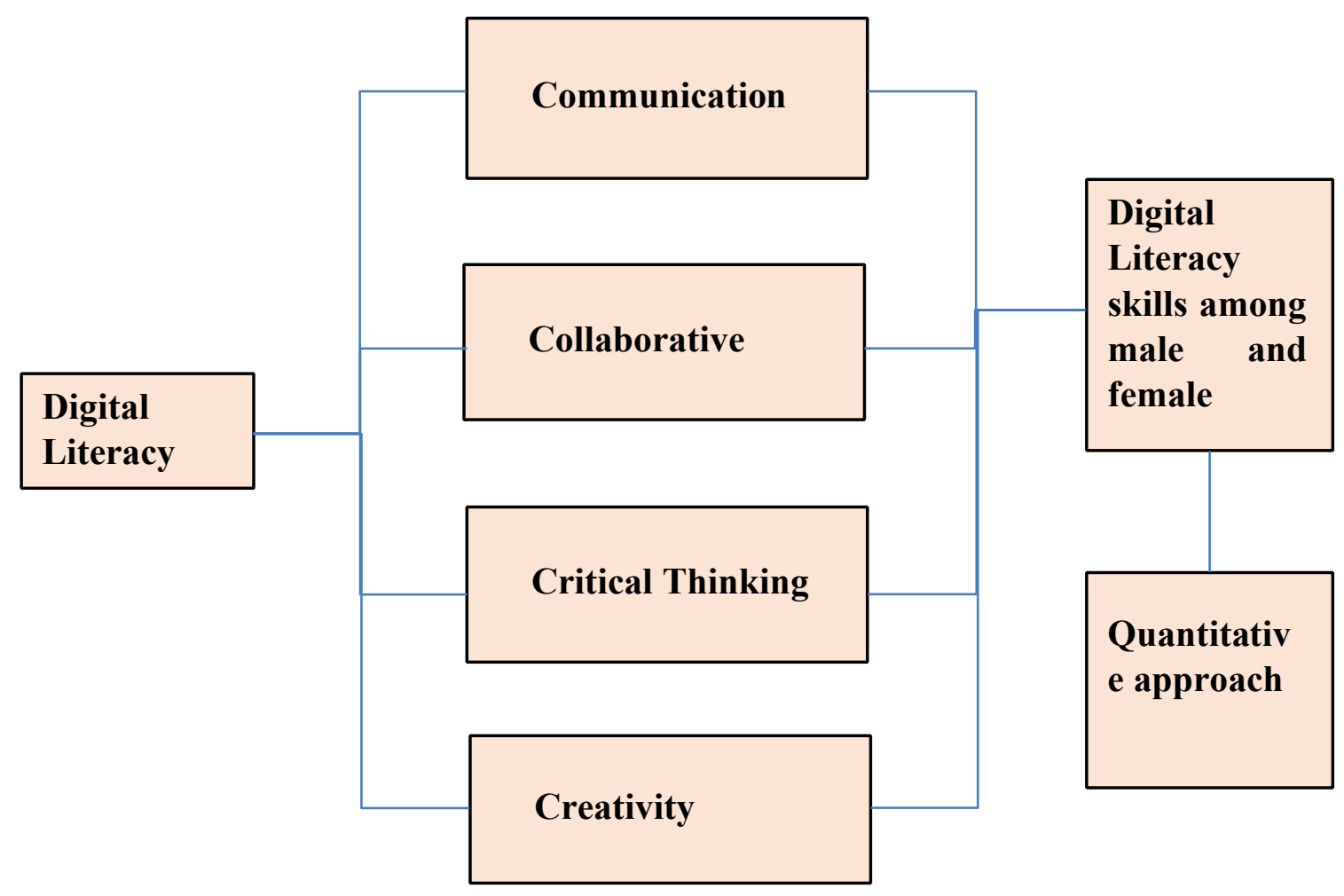

Figure 1. Framework

\section{LITERATURE REVIEW}

Digital literacy occupies an onerous standard in society especially when it comes to its support in socializing, coming across numerous cultures, and raising the economy through digital devices and the network of the networks. For example, all the tech-savvies attain the essential education from all the institutes, especially where digital literacy is adopted and taught to students where all students get compulsory education and attain the Information communication technology skills, (E Çam; 2017). Digital literacy has a major role in the field of education in shaping our lives. Undoubtedly, 
instructors and professors are responsible to bring about revolutionary updates in the methodology of providing education using the skills and grasp over computer technologies, because this has become the sole option to cause developing revolutions to compete with the advanced and leading ways of economic achievements all over the world(A Abuhmaid: 2011). For this, teachers are supposed to be familiar and have a good grip over advanced technological aspects as they have to fulfill their day-to-day tasks. Keeping this point in view, appropriate training and effective awareness will be sufficient and encouraging to develop interest among the teachers regarding the usage of digital literacy. Moreover, it is believed that eagerness of teachers augments the determination and enthusiasm to learn the specific knowledge of digital literacy; when teachers come to know that digital literacy supporting programs are utmost for enhancing their skills also to become intelligent tech-savvies in the ways of teaching without any confusion. (Z Tasir: 2012).

ICT becomes an important portion of our lives for the final few decades, which is influencing our society as well as individual life. ICT in today's time is mostly used in the educational world. Administration, faculty, and students, and every person related to education commonly use ICT. ICT is also used by teachers to make instructional activities much better for students. In this modern era of technology, Every society demands education with technology and teachers need to know digital literacy. Indeed, in this advanced era of the twenty-first century, none of the professors or instructors, either of urban or rural, of any institute can manage the tasks without the usage of modern technologies. Owing to the essential need for technologies, myriad educational places are providing the intangible advanced resources which assist teachers and students at every step of academic activities. (Z Sahito:2017). For a better and successful education system, it is important to integrate Information communication technology in Education. Digital literacy is our need in this modern period. Every person from student to businessman is using ICT in their lives. Hence, a major revolution is when students use ICT and know the forms and methods of use of IC(L Herout:2017).

The proficiency of Digital literacy is also important for prospective teachers in their instructional or pedagogy training because integrating ICT perception can give a better way to know the world of applied science and can be used better in the future for the benefit of Students( Bhattacharjee B;2016). Furthermore the $4^{\text {th }}$ goal of Sustainable Development Goals (SDGs) for Education, it becomes important in the 21st century to integrate digital literacy in the academic and National policy of Education of Pakistan (2017) has also focused on this and make it necessary to integrate Information communication technology in Education. Although NPSTs in Pakistan, the $7^{\text {th }}$ standard for teachers has also focused on powerful communication and the use of Digital literacy in Teacher Education. Prospective are the main factors in the integration of ICT in education but they need to be digitally literate. In reflecting this A.Azlan in 2017 said in his research that Prospective teachers should get knowledge of digital literacy (ICT) as the will able to integrate Information communication technology in their instructional process. Teacher education, beginning from pre-service education, is a key to the actual integration of technology education in classroom practice. (L Botturi, 2019) Whereas, Melissa Bond in 2018 finds that, for the transformation of digital technology in educational institutions, it is important to learn and understand the basic knowledge of both teaches and students, so that we should find the respective needs in Integration of ICT. According to AJ Khokhar (2016), Teachers' attitude towards ICT and their perceptions of ICT effectiveness plays an important role in their making use of ICT in their teaching and assessment activities in the classrooms. He further found that both the 
students and teachers believed that ICT is a very important tool to maximized learning in the classroom and the use of ICT creates authentic teaching and learning in the classroom.

The expert teachers in technologies are demanded educational triumph. If they are expert at digital literacy, the schools and universities can be driven towards modernity drastically (MSH Khan, 2017). Tondeur et al. (2013) suggested that "ICT should be added into the entire curriculum so that pre-service teachers have the opportunity to (a) understand the educational reasons for using ICT and (b) experience how ICT can support teaching and learning across different subject domains". But the research of G.B Gudmundsdottir ( 2018) found that newly hired teachers have a poor quality of and contribution of ICT in their training programs. It is reported that fledgling qualified teachers can have both good and bad experiences with digital literacy in institutions. As some teachers, despite having a good attitude towards digital literacy, think that technologies can cause distraction from concentration in the classroom. An Istenic Starčič (2016) noted that teachers are not much confident in using information communication technology in their teaching and for that, they can not prepare their students to be confident in the use of ICT. Allen (2015) found that despite development in digital literacy, many teachers depend upon books to make the course plans despite using digital tools. The demand for good teachers, who should know digital literacy, does not mean that they should have a profound knowledge of technologies. They are supposed to be familiar with the basics of such advanced aspects to drive the institutes triumphantly and to know to be familiar with technological pedagogical content knowledge(J Voogt: 2016). The procedure of opting for and acquiring resources and implementing them in day-to-day activities demands sufficient and significant knowledge of their effective usage. It is onerous for the teachers to be capable of implementing all the necessary aspects of digital literacy in schools, colleges, and universities to compete with the developing era of modern technologies.

Table 1. Literature Framework

\begin{tabular}{|c|l|}
\hline $\begin{array}{c}\text { Name/Year } \\
\text { L Botturi } \\
2019\end{array}$ & $\begin{array}{l}\text { Contribution } \\
\text { Found pre-service teachers believe in the importance of DML for their profession } \\
\text { and their pupils. }\end{array}$ \\
\hline $\begin{array}{c}\text { Melissa Bond } \\
2018\end{array}$ & $\begin{array}{l}\text { She explained which information and communication technology is currently used } \\
\text { in instructional processes, according to data that was taken from students and } \\
\text { teachers at a mid-sized German university. }\end{array}$ \\
\hline $\begin{array}{c}\text { GB } \\
\text { ttir } \\
2018\end{array}$ & Study the Newly qualified teachers' professional digital competency in Norway. \\
\hline $\begin{array}{c}\text { E Çam } \\
2017\end{array}$ & Analyzed the Digital literacy level of the prospective teachers in terms of gender. \\
\hline $\begin{array}{c}\text { Bhattacharjee } \\
\text { B } 2016\end{array}$ & To find out the key purpose of ICT in the 21st century in Teacher Education. \\
\hline $\begin{array}{c}\text { Z Saito } \\
2017\end{array}$ & $\begin{array}{l}\text { This research was carried to get a much comprehension of TEs-knowledge, } \\
\text { experience, skills, and situation to the job, satisfaction in the job, and ICT. }\end{array}$ \\
\hline
\end{tabular}




\begin{tabular}{|c|c|}
\hline $\begin{array}{l}\text { L Herout } \\
2017\end{array}$ & $\begin{array}{l}\text { This study examines the use of current digital technologies in the educational } \\
\text { environment, more important it is used in students' pedagogy training. }\end{array}$ \\
\hline $\begin{array}{l}\text { MSH Khan, } \\
2017\end{array}$ & $\begin{array}{l}\text { This study examines the teaching methods of teachers in information and } \\
\text { communication technology (ICT) that have improved teaching in higher education. }\end{array}$ \\
\hline $\begin{array}{l}\text { AJ Khokhar } \\
2016\end{array}$ & $\begin{array}{l}\text { This study map out the access and usage of ICT devices, identify how students and } \\
\text { teachers use it in their classrooms, identify the gaps between teachers' use of ICT } \\
\text { and whether students' idea of ICT use in classroom matched with this and which } \\
\text { obstacles are faced by teachers in their school settings while planning and executing } \\
\text { ICT integration in the classrooms. }\end{array}$ \\
\hline $\begin{array}{c}\text { An Istenic } \\
\text { Starčič } 2016\end{array}$ & $\begin{array}{l}\text { This study examined the impacts of an integrated approach in ICT competency } \\
\text { development of preservice teachers. }\end{array}$ \\
\hline $\begin{array}{l}\text { J Voogt } \\
2016\end{array}$ & $\begin{array}{l}\text { This study is designed to explore how TEIs help students develop the TPACK } \\
\text { needed to make better use of technology in early learning. }\end{array}$ \\
\hline $\begin{array}{c}\text { Aydan Aslan } \\
2015\end{array}$ & $\begin{array}{l}\text { Impact of prospective teachers' knowledge concerning information communication } \\
\text { technology integration in education on their teaching practices in Turkey. }\end{array}$ \\
\hline $\begin{array}{l}\text { J Tondeur } \\
2013\end{array}$ & $\begin{array}{l}\text { This study aimed to explore how the TEI curriculum prepares pre-service teachers } \\
\text { for the integration of ICT }\end{array}$ \\
\hline $\begin{array}{c}\text { Z Tasir } \\
2012 \\
\end{array}$ & $\begin{array}{l}\text { The findings show that teacher's competency, teacher's confidence level, and } \\
\text { teacher's satisfaction toward ICT programs. }\end{array}$ \\
\hline $\begin{array}{c}\text { A Abuhmaid } \\
2011\end{array}$ & $\begin{array}{l}\text { The primary purpose of this study was to explore Jordanian teachers' experiences } \\
\text { with ICT training courses adopted by the Ministry of Education. }\end{array}$ \\
\hline
\end{tabular}

\section{RESEARCH METHODOLOGY}

In this section, we have tried to describe the process of collecting data and its sample size. The data will be collected from the students of the Education Department of Sukkur IBA University. To collect data we will target approximately 200 students from the Education Department. The students that will be targeted belong to different regions of Pakistan.

Research design:

A survey research design has been chosen for our research study.

Research Instrument

To collect the data a questionnaire has been adapted from a research study "Teachers and Information Communication Technology in Saudi Arabia: Current Use and Training Needs" conducted By Hamad Abdul Aziz Al-Rashed in May 2002, a Thesis Submitted for the Degree of $\mathrm{Ph} . \mathrm{D}$. in the University of Hull.

In this questionnaire level of competency of teachers towards ICT skills, their Attitude towards ICT, their use of ICT in teaching and learning process, and how much they are up to date has been asked. 
Data analysis

This study will be a comparative study of male and female prospective Teachers. The collected data will be analyzed through T-Test and Descriptive analyses using SPSS 22.0 software.

\section{FINDING AND DISCUSSION}

Expected Outcomes

As this study is taking from the Prospective students of Sukkur IBA University where the students came from different areas of Pakistan specifically Interior Sindh so this study will provide a significant contribution to the administrators in enhancing guidelines and policies for the betterment of current curriculum and will help in achieving the university vision and objectives pers.

This study will also facilitate the stakeholders to design appropriate strategies for integration of ICT in the teaching and learning process to deal with the unexpected and sudden changes in circumstances such as world pandemic COVID-19 due to this education sector being fully closed. In this situation, if we have digitally literate teachers so they can vary their students about viruses and other things and can also take their classes from home using technology. Further, it will be beneficial to the stakeholders by "changing the mindset" from traditional to 21 st century needs as they will know about twenty-first-century skills and a gap in the teaching and learning process.

\section{CONCLUSION AND FURTHER RESEARCH}

\section{Expected Outcomes}

As this study is taking from the Prospective students of Sukkur IBA University where the students came from different areas of Pakistan specifically Interior Sindh so this study will provide a significant contribution to the administrators in enhancing guidelines and policies for the betterment of current curriculum and will help in achieving the university vision and objectives pers.

\section{REFERENCES}

Belias (2013) Dimitrios, B., Labros, S., Nikolaos, K., Koutiva, M., \& Athanasios, K. (2013). Traditional teaching methods vs. teaching through the application of information and communication technologies in the accounting field: Quo Vadis?. European Scientific Journal, 9(28).

E.M.M.Asad (2014) Asad, E. M. M., Hassan, R. B., \& Sherwani, E. F. (2014). Instructional models for enhancing the performance of students and the workforce during educational training. Academy Arena, 6(3), 27-31.

Sheila M.Smith (2005) Smith, S. M. (2005). The digital divide: Gender and racial differences in information technology education. Information Technology, Learning, and Performance Journal, 23(1), 13.

Christine Heward 2018.

Dorothy Williams (2000) Williams, D., Coles, L., Wilson, K., Richardson, A., \& Tuson, J. (2000). Teachers and ICT: Current use and future needs. British journal of educational technology, 31(4), 307-320.

MN Tunio (2013) Tunio, M. N., Arain, N. R., \& Tunio, S. P. (2013). Assessment of computer literacy at the secondary education level in rural areas of Sindh (Pakistan). International Journal of Emerging Science and Engineering (IJESE) ISSN, 2319-6378. 
R.Dimeralay (2010) Demiralay, R., \& Karadeniz, S. (2010). The Effect of Use of Information and Communication Technologies on Elementary Student Teachers' Perceived Information Literacy Self-Efficacy. Educational Sciences: Theory and Practice, 10(2), 841-851.

MO Yousuf (2011) Yusuf, M. O., \& Balogun, M. R. (2011). Student-teachers' competence and attitude towards information and communication technology: A case study in a Nigerian University. Contemporary educational technology, 2(1), 18-36.

GB Gudmundsdottir (2018) Gudmundsdottir, G. B., \& Hatlevik, O. E. (2018). Newly qualified teachers' professional digital competence: implications for teacher education. European Journal of Teacher Education, 41(2), 214-231.

Melissa Bond (2018) Bond, M., Marín, V. I., Dolch, C., Bedenlier, S., \& Zawacki-Richter, O. (2018). Digital transformation in German higher education: student and teacher perceptions and usage of digital media. International Journal of Educational Technology in Higher Education, 15(1), 48.

Aydan Aslan (2015) Aslan, A., \& Zhu, C. (2015). Pre-Service Teachers' Perceptions of ICT Integration in Teacher Education in Turkey. Turkish Online Journal of Educational Technology-TOJET, 14(3), 97-110.

G.Sang (2010) Sang, G., Valcke, M., Van Braak, J., \& Tondeur, J. (2010). Student teachers' thinking processes and ICT integration: Predictors of prospective teaching behaviors with educational technology. Computers \& Education, 54(1), 103-112.

Jo tondeur (2007) Tondeur, J., Van Braak, J., \& Valcke, M. (2007). Curricula and the use of ICT in education: Two worlds apart?. British Journal of Educational Technology, 38(6), 962-976.

T Anderson (2008) Anderson, T. (Ed.). (2008). The theory and practice of online learning. Athabasca University Press.

GB Gudmundsdottir (2017) Gudmundsdottir, G. B., \& Vasbø, K. B. (2017, March).Toward improved professional digital competence: The use of blended learning in teacher education in Norway. In Society for Information Technology \& Teacher Education International Conference (pp. 499-509). Association for the Advancement of Computing in Education (AACE).

AK Bingimlas (2009) (Bingimlas, K. A. (2009). Barriers to the successful integration of ICT in teaching and learning environments: A review of the literature. Eurasia journal of mathematics, science \& technology education, 5(3).

Bhattacharjee, B., \& Deb, K. (2016). Role of ICT in the 21st century's teacher education. International Journal of Education and Information Studies, 6(1), 1-6.

Saeed, N., \& Fatima, A. (2015). Educational inequality in rural and urban Sindh. The Pakistan Development Review, 767-777.

Çam, E., \& Kiyici, M. (2017). Perceptions of Prospective Teachers on Digital Literacy. Malaysian Online Journal of Educational Technology, 5(4), 29-44.

Khokhar, A. J., \& Javaid, S. (2016). Student's and teachers' perceptions of ICT use in the classroom: Pakistani classrooms. The Asian Conference on Technology in the Classroom.

Khan, M. S. H., \& Markauskaite, L. (2017). Approaches to ICT-enhanced teaching in technical and vocational education: a phenomenographic perspective. Higher Education, 73(5), 691-707.

Istenic Starčič, A., Cotic, M., Solomonides, I., \& Volk, M. (2016). Engaging preservice primary and preprimary school teachers in digital storytelling for the teaching and learning of mathematics. British Journal of Educational Technology, 47(1), 29-50.

Voogt, J., \& McKenney, S. (2017). TPACK in teacher education: Are we preparing teachers to use technology for early literacy?. Technology, pedagogy and education, 26(1), 69-83

Abuhmaid, A. (2011). ICT training courses for teacher professional development in Jordan. Turkish Online Journal of Educational Technology-TOJET, 10(4), 195-210.

Tasir, Z., Abour, K. M. E. A., Halim, N. D. A., \& Harun, J. (2012). Relationship between Teachers' ICT Competency, Confidence Level, and Satisfaction toward ICT Training Programmes: A Case Study among Postgraduate Students. Turkish Online Journal of Educational TechnologyTOJET, 11(1), 138-144. 
Sahito, Z., \& Vaisanen, P. (2017). Effect of ICT Skills on the Job Satisfaction of Teacher Educators: Evidence from the Universities of the Sindh Province of Pakistan. International journal of higher education, 6(4), 122-136.

Herout, L. (2017). Information and Communication Technology in Education of Prospective Teachers of non-ICT Fields of Studies. In Rural Environment. Education. Personality. (REEP). Proceedings of the International Scientific Conference (Latvia). The Latvia University of Agriculture.

Botturi, L. (2019). Digital and media literacy in pre-service teacher education. Nordic Journal of Digital Literacy, 14(03-04), 147-163.

Tondeur, J., Roblin, N. P., van Braak, J., Fisser, P., \& Voogt, J. (2013). Technological pedagogical content knowledge in teacher education: In search of a new curriculum. Educational Studies, $39(2), 239-243$ 